\section{Brigiual \$nticleg.}

\section{INJURIES ABOU'T 'THE SHOULDER A'T BIRTII.}

"IY .. S. STONH, M.L., Bositox.

I Have been much interested in the injuries and deformities aloout the shoulder which are seen not infrequently in the elinies at the Children's and Infants' Ilospitals. Most of these casses come morler the general heanl of obstetrical injuries, and in most of them I have become convineed, partly from obsere vation and partly from the rather scanty and very contradictory literature on the subject, that injury to the brachial plexus is by far the most important facetor, while direct injury to bone and joint is of only seceondary importiunce.

It hats long been recognized that obstetrical patralysis is of lintis type, thith the deltoid is the muscle most seriously affected, and that the other muscles paralyzed are the supria- and inf fia-spinatus, teres minof, biecpes, and brachialis anticus, together with the supinators. In some of the severer casess paralysis of some of the extensors of the wrist, or more especially of the tingers, also oceurs.

All of the paralyzed muscles are supplied by the circumflex, supmescepular, musculocutaneons, and musculospiral nerves, including with flere last its branch, the posterior interosseous. Of these merves the circumflex, suprascapular and musenloculatueous arise entirely from the fifth and sixth eervieal roots. In obstetrieal partalysis these nerves are most seriously affected and every muscle supplied by them is usuatly paralyzed, excepting only the comcolstachialis, which is also supplied in infiuncy by al seppirate branch derived from the seventh cervicial root.

The only other nerves which arise regularly from the fifth and sixth eervical roots are these to the scaleni, to the rhomboids, and to the subclavius, the posterior lhoracic, a part of the external anterior thoracie, a very small pant of the median, and her "lper and lower subscapoulor, together with a small part of the musculospiral. ()f these nerves the filmeses which go to supply the scaleni, the rlomboids and the subelavius, and the fibres going to the pesterior thoracic, leave the roots of the plexus almost inmediately after their exit from the spinal camal and before the roots have joined to form the cords of the plexus. Furthermore, all of these nerves take a dereidedly different course from the other nerves of the plexus. They do not go ontward toward the shoulder. 'The pectoral and the subscapulare muscles are silpplied only in part by nerve fibres arising from the two "lper roots.

$\Delta s$ to the callsation of the paralysis, 1 will mention, first, a theory which has beenl hedil somewhiat in (icermany, and which hats been punt forward in this commtry hy Burr." It is, in lorief, that the lesion is a hemorrange into the anterior horus of the cord, dine to the congestion arising during birth. liurr argues in favor of this theory that sensation is mimpaired. llis oppononts reply that in infints this is an extremely fallacions sign, that complate lecovery from an anterior poliomyelitis is rarely, if ever, sceen, and that it is extraordinary that such a lesion should always occur at one particular spot. Furthermore, 1 lRead boforo tho Boston siocloty for Medical Improvenent, lith-
ruary, 5 , 1000.

Boston Modionl und Surgioul Jomrnal, vol. cxxvii, p. 235. as Carter" points out, injury to the fifth and sixth cervical roots at or before their exit from the spinal canial may be exeluded by the fact that the serratus magmus and the rhomboids, thomgh supplied by neerves leaving these roots very soon after their exit from the comal, are never parralyed. In other words, the Jesion must be at a print below the origin of the fibres going to the pesterior thoracese, to the rhomboids, and scalleni.

The other theories of the cillsation have been many. The theory of elired pressure on the plexus in the side of the neck, or axillat, by the blate of the forceps, the finger, or the hook, hats been thoroughly discredited by the work of ('arter, and more lately by

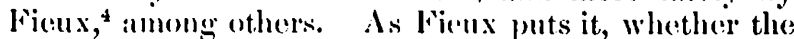
delivery be spontaneons, or whether extraction of the shoulders is mecessiry, whether coming on after the nse of foresps or alter it brecen delivery, Erb's point is al way's pressed npon, and in one case by the posterior exge of the claviele, in another by the fingerers, in another by the edge of the forceps blade. Ex planations of this sort obvionsly presuppose too much.

This brings up a point in regand to the etiology, on which there has been considerable discussion, the theory that the praralysis is due to a pinching of the plexus at Erb's point between the posterior edge of the cliviele and the lirst rilo in cases in which the shonlder is carried far back. Some hold that the pinching of the plexits oecens between the elaviele and the tramsverse processese. 'lhese views are held by (Opprohlesim, (xanlt, Roulland, Budin, and of late have been anduanced in Boston loy Walton, ${ }^{b}$ after anatomical study of a fetus at, tereni, and more lately still by Sohoomiker." 'This pressure of the elavicle against the first rile, or the transverse processes, is an anatomical possibility. It means, however, that the shoulder must be carried considerably downwatrd and very fall backwarel to a degree which is at least not likely to oceur during childibirth, although the theory that the pinching results from the rotation of the head, with the anterior shoulder hung up on the pubes, is attrative.

In the dissecetions on six bahies which I have made the anterior curve of the claviele save ample space for the plexus not to be arowded. My conelusions agree alsolutely with what I have since loamed Fieux hand done, but with which Schocmaker doess not contirely angee; work bearing out in every wiy the theory ably set forth by ('arter, that the paralysis is due to merve strotching, and, in extreme cases, to nerve tearing.

'The plexus arises from the fifth, sixth, seventh and cighth cervical, and tirst dorsal, herves. If the shoulder is lowered it is platin thith the uppere cords must be stretehed more than the lower, becanse the lower hatre normally a more nearly horizontal course. 'This is entirely covilirmed on the cadtover. 'The upper two roots hecome as tight as bowstrings when the shoulder is lowered, while the lower three remain perfectly lax until the mpper cords are severely stretched, or even completely ruptured. A pull down on tho shoulder of abont difteen pounds is suflicient to break the upper roots when the plexus alone holds the shoulder up. $\quad \Lambda$ pull of about forty-five pounds, or three times an much, does the same thing when every-

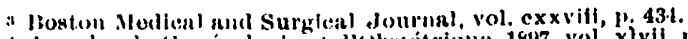

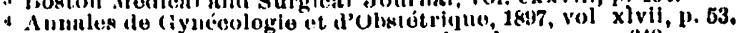

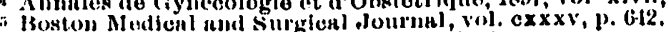

" Goitbohifit f. (iobutsh. W. (iynakol., xil, i. 
thing is intact, except for a small incision through which to wateh the plexus.

Fienx showed experimentally the anount of the sepraration of the cent roots of the brachial plexus when the shonlder was held down and the head catrried to the opposite side with as mueh foree as oceurs in an ordinary delivery. Il. found that the upper. two cords sepparated from 26 to 28 millimetres, the third only 12 and the lower two only eight. In other words, the Ilpere two separated more than three times as much ats the lower, and more than twice as much as the midale. The separation valies with the amount that the head is inclined to the opposite shoulder. It likewise vallies with the annount that the shoulder is depressed.

The point at which rupture oceurs, experimentally, is from aloout a cuatere to half an inch from the emergence from the spinal canal, at, or near the junction of the fifth and sixth cervical roots. The filores of the suprascapular nerve may be ruptured here or at a point slightly lower. They alle always ruptured among the first. 'This point is a little lower' than that mentioned hy Fienx, who states that rupture oceurred five or six millimetres from the emergence of the nerves. The distance seems to be determined by the strength of the fibrous sheath which surrounds the nerve bundles. Vrery near the canal the prolongattions outward from the dura prevent injury to the nerves. Farther out it is determined by is certain weakest point.

One very inportant point mentioned by Walton, which is admirably shown experimentally, is the fact that the suprascapular nerve must be severely stretehed or ruptured, because it has a comparatively short course and what may be termed it ver'y definite distal attachenent where it passes through the suprascapular notels. Similarly, though to a less marked degree, the cireumflex has a short course and a definite distal attachnent where it winds ahout the humerus. In other words, these two nerves have lut a short distance in which they can accommodiate themselves to stretching.

Fieux produced by traction on the necks of rabbits, separating the head from the shoulder, a similar parrtial paralysis of the foreleg, but did not report the results of post-mortem eximninations.

Cases reported by Phillips, Beevor, and Walton show similarly that a violent separation of the head from the shoulder may, in adults, cause a paraly'sis of Erb's type.

A degree of asphyxia leading to a loss of all muscular tone would obviously increase the dingger of injury to the nerves.

In regard to the theory that fracture or dislocation of the bones may cause obstetrical paralysis, it sluould be remembered that paralysis from this canse in adults is not usually of Erlo's type. Furthermore, certain anatomical facts in regard to the bony development at birth must be considered. 'Tlhe elaviele is osseous, except at the two ends, ossification beginning here earlier than in any other bone. The sternal and acromial ends are cartilaginous. The seapulat at birth is cartilaginous along jts whole innes horder, at the angle, and in the acromion and coracoid processess. The main part of the body, the spine and the glenoid fossa are ossified.

The humerus at birth is ossified thronghont the shaft; the hear is cartiliginous. 'Thus the outer end of the clavicle, the coracoid and acromion processes.s. are all cartilaginous and are all firmly united by strong ligaments. These parts making up the prominence of the shoulder are so freely movable and so strongly held by liganents that injury to them is execedingly mulikely to oceur during birth. Injury to other parts is very much more likely to oceur. Experimentally the cartilaginous head of the humerus is separated with great eatse. The glenoid cavity may be hroken off entirely by the exereise of considerably more force. 'The claviele may be broken in its bony' portion. 'Ilae bony shatt of the humeres may be easily broken. Julyging from what is secen experimentally, separtation of the eatrilaginous heal of the humeris must, be of extremely common oceurence during birth, and must often pass entirely mrecognized and indeed give rise to no symptoms, except the suljective one of pain, with perhatjs a very soft cerepitus which it would loe impossible to detect with certainty during life. A iracture of a portion of the glenoid it is impossible to produce experimentally. The whole engenoil may lo. broken off. 'This would be an injury detected also with difliculty. Frateture of the elieviele and of the shate of the humerus is in each calse alph to ocear alout the middle of the bone and is detected with case. Experimentally, these fractures occur comparatively so easily that it is impossible by the use of any reasonalle anount of fores to dislocate the head of the humeriss and pratically absolutely impossible to dislocate the head of the humerus, if the word dislocation is used in the sense of forceing the head out of the glenoid through a rent in the capsular ligament. It is possible, with considerable foree, to stretch ind tear some fibres, particularly abont the lower posterior part of the capsisule.

It is perfectly conceivalle that injury to the brathial plexus, through fracture of the ciavicle, might cause paralysis of Wrls's type, but it is likewise ineonceivalle that a fracture of the clavicle should very often patss undetected where there is an obstetriesil paralysis. It is not possible for injury to any other hone than the chavicle to cause a paralysis of Erb's type.

It is, nevertheless, true that at considerithe number of casses ane recorded in which there is a backward displacement of the humerus, usually with paralysis of Er:b's type, ranesly withont. My feeling in regarert to these cases is that the dislocation, which is usually in the reports considered congenital, is in reality dure to the paralysis; that is, that it is due to a slow yielding of the posterior part of the capsular ligannent minder the pull of the internal rohators. 'This form of dislocation was deseribed by Dechenne in Ixcici. Onc case of backward dislocation hats develuped within my own observation during the necond $y$ ear of life. 'The child hat a typical obstetrical parralysis, occurring after a version. When first seen the head of the lumerus rested in the glenoid and conld be slipped barek onto its posterior Forder. When seen, a scant year later, the head rested ontside of the glenoid and could be slipped forward onte its posterior border. 'This child hats turned out to be micerocephalic.

Another casse hail typical obstetric paralysis noticed immediately after birth, and examined hy the family physician, 1)r. ('ahill, of ('ambridge, who is positive there was no dislocation at first. I saw the olitd first at six montlss of age, when it was secen again by l)r. ('allill. 'The dislocation wats then most striking. 
Dislocation of this sort secondary to paraly'sis, whether or not accompanied hy more or less tearing and stretehing of the eapsule at the timc of the injury, is male much easice lyy the relatively small size, at birth, of the glenoid andity as ampured with the? head of the humerus. (of course the disproportion is obvious in alults, but in infants at term the joint surface of the glenoid is in breatth only a quarter to a thirel of the diameter of the joint surface of the head of the lummerus, while in alults it is ome-half as large. In other words, the glenoid anvity is relatively from half as large again to twice as large in the alult as in the baby.

In obstetric paralysis the position of the arm is ehataceteristic. It hangs at the side, rotated inward strongly, with the elbow slightly flexed, the forearm pronated so that the palm faces backward and outward and the wrist and lingers flexed. 'The most marked muscular atrophy is in the supura-and infra-sponati and deltoicl. 'The prectoralis major and the subseapularis mopposed by any outwarl rotator keep the arm so strongly rotated inwarel that the head of the humerus is constantly stretehing the posterior portion of the capsule. This stretching is increased by the backward and the downwarl pull of the latissimus dorsi. "The result is a contracture of the pectoralis major and a gradual yielding of the weak posterior portion of the eapesule. $\Lambda$ backward displacement incvitably follows. 'The stronger anterior portion of the (apj)sulat ligament and the coracolomeral ligament, which at first preventerl any forward dislocation, ale not developerl nommally, and together with the contracture of the pecensalis major, hincler the rotation of the arm outward and the replacement of the head of the humerus in the slenoid cavity. Secondary hony elanges may oceur both in the glenoid anvity and in the hean of the humerus. From disuse of the arm, lack of growth is common. It is possible that in some enses more or less recovery of power may oceur in the deltoid and ontward rotators, even after considerable displacement of the lecad of the humerus has oceured. 'This is probaloly the manuer of production of most of the so-called eomentental distocations of the shoulder, which is, therefore, nsually a misnomer.

There ane three classes of infintile dislocations of the shoulder. 'The first includes the true eongenital clislocation, where the lesion is due to a true lack of development during intranterine life of the glenoid avity and the heaf of the humerus, analogous to the congenital dislocation of the hip. 'This form of dislocation, however, is extremely lane, and many atses reporterl as congenital dislocations are probibly in reality panalytic: dislocations. While: 1 lack of ilevolopment in the acetabulum is the most frequent congenital defeet in the pelvis, in the shomlder giodle? congenital ilefect of the grlenoid is less commont than other malformations, such as absemes of the clavicle, congenital elevation of the seapula, exostosis of the scapula, or defect of its lower portion. Latek of development in later childluod or in arlult life eamot in any sense be taken to indicate that the dislocation is truly congenital, for in severe cases of obstetrical paral$y$ sis lack of development is eommon. ${ }^{7}$ 'The association of paralysis with cases regraldod as congenital dislocat-

7 Une Endémie de Paralysios Radiculatros Obstétricales. (inillor-

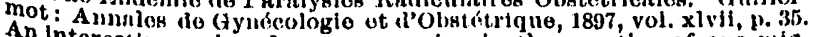
An interesting geries of chses occurring in tho practice of one miawife, and probably uanally duo to diffeulty in delivering tho hond after verston before full dilatation had ocenrred. tions should leal to the suspicion that the paralysis was the cause of the dislocation, and especially should this be suspected in cases in which there is reason to believe that the paralysis arose from trouble during delivery. If the cases reported as eomgenital dislocations of the shoulder are studied in this way, a large majoity of them mist he looked upon as probably of paralytice origin.

Another class of infantile dislocation is the tratimatic. It is moloubtedly possible that this may be produced during delivery. Experiments and elinical experience, however, both show that this must be aif extremely rare occurrence, simply because any violence sufficient to foree the heal of the humerus through the apsular ligament would almost invariatbly produce other injuries which would allow the sliouleler-joint itself to escatpe.

$\Lambda$ vast majority of the cases of infantile shoulder dislocations must be regarded as paralytic. The displacement may have been aided by rupture or streteh ing of the posterior part of the eapsule at birth, but they are not true dislocations in the sense that the head of the humerus has passed through a rent in the capsular ligament. 'They are due to a gradual yielding of the ligament under a constant mopposed muscular pull in one direction.

Before speaking of treatment something should be sajel regarding prophylaxis. 'Traction is the cause of obstetrical panalysis. ()' course it is often absolutely necessiry to use extremely severe foree in delivery where the choice must often lie between injury to or death of the elidk. 'There are certain times, however, when traction direetly on the shomlder may be avoided. Particlarly in delivering an after-eoming head, the pull may be exerted on the pelvis and chest rather than on the shoulders. Indelivering the shoulders after the hearl is born, direcet traction is much more apt to cause paralysis than is the frecing of the shoulders by insertion of a finger in the axilla,- a manenvre likely of course to fracture the humerus. 'This aceident, however, is far less serious than a paralysis. The suggestion of Waltom that the second stage of labor is to be hastened should be limited by the other rule that it should not be shortened by any measure prosheing traction on the shomliler's.

$\Lambda$ fter the injury is done, support for the arm is essential. 'Thus further dragging on the stretehed nerves or separation of their torn ends is prevented, the strelched ligaments are supported and the moseles aregiven a chance to recover their tone. The muscles should be protected from molue stretehing just as in the early stages of infantile paralysis.

'Thus for a time further harm is prevented. later, massage and olectricity have their uses. By these simple measures, or even withont trentment recovery will oceur in probaloly a considerable majority of the ases. The olsstetricians thus regrard obstetrical paralysis rather lightly, while the neurologists and orthopertic surgeons, who only see those cases which do not recover, regard the prognosis as bat. 'This difference is lue probubly to the varying degree of injury to the nerves; in one case simple stretching, in another it rupture of certilin fibres of a nerve, and in the most. screre possibly a complete tearing apart of the whole nerve. In eases not improving decidedly within the first six or eight weeks of life a serious injury to the nerves is to lo regarded as probable, and cousequently the outlook for marked im- 
provement is poor, although improvennent has occurred after yours.

It is a question whether in comain cases the injury eannot be repation by surerical interference. 'The greatest obstacle to any suceessful nerve suture is that in all probability the nerves are torn by indiviclual fibres as a hemp rope tears, not directly across at any one point. Furthermore, after severil weeks there would probahly be the gleatest dilliculty in recogni ing in the small serves of the baby any abnormality without considerable manipulation. A iml during the interval of wating for improvement to oc(enr, all as cending degeneration of the tom filores would probat bly have oceurred which would interfere with a restoration of function, even after apporoximation of the torn onds. Exploration is possible, lowever, even in small baljies.

In the lower part of the posterior triangle of the neck the upper brachial plexus is comparatively easy of acecess. It lies back of the stepromastoicl, aloove the omolyyoid, in front of the traperius. The scalemus anticus and the sternomasteicl protect the great vessels and the phrenic: nerve. 'Tlue spinal aceessory nerve is considerably belind the plexus. 'The subclavian vessels, thoracie luet and several small arterices rumning across the neck are all below the omohyoirl.

The external jugular vein and the branches of the cervical plexus which, wind around the posterior border of the sternomastoin are in danger. 'The dithiculty in reaching the mpler cords of the plexus lies chiefly in the sliortness of a haby's neck. 'The ontlook for snceessful interference, however, is doultful. In one case, in a baby of six weeks, I have cut down on the plexus, but found nothing more, that a rather soft spot just helow the junction of the fifth and sixth roots. 'IJe ehild died of pneumonia two weeks after' operation. In the older cases where dislocation has oceurred probsebly little is to be hoped from nerve suture, although exploration is justifiable.

Leaving aside the possibility of any radical care: of the condition through repair of the nerve injury and eonsequent restoration of power in the paralyoed muscles, several palliative measures are to be considered. 'The condition always present and the one for which relief is most often sought is the inward rotation of the arm. 'The jualjility to elevate the alm and the other paralyses vary considerably in degree. For the relief of the inward rotation, stretehing or section of the contracted pectoralis major is necessary. $\mathrm{By}_{\mathrm{y}}$ means of plaster bandages applieel with the forearin flexed to a right angle and the arm rotated ontward with the ellow at the sille, it is a simple matter in the course of a few days or weeks to overeome the inward rotation and hy direcet pressure to hring the heal of the humerus lanek into the glenojol cavity, if it is dislocated. It is possible that in a few casces rest of the over-stretehed outward rotator's maly thus enable them to recover their tone and bring about some improvenont. Relapse will almost surely occur, however, unless systematic passive motion and massage is used, aided ly some orthopedic apparatus to check in ward rotation.

In the more marked cases of longer duration section of the contracted muscles will cause a considerable improvement, but here again systematic aftertreatment is essential. Soveral cases, among them one of my own, thus operated upon have been somewhat benefiterl.
The operative procedure of Phelps ${ }^{8}$ consists in deepening the glenoid cavity, paring of a portion of the head of the lumerus and stitching up the lax posterior portion of the alpsular ligament. His procedure is based upon the beliel that the dislocation results from a frature of the posterior portion of the glenoid eavity occurring at birth. In one cass: in which I opened and exploreet the shoulder-joint in a boy six months old with a typical patalytic dislocation I foumd no evidenee of malformation or fiacture of the grenoid or heat of the humerus. Sititehing ul more snugly the posterior ligaments caused slight inpovement, althongh in his case systematic stretching of the anterior museles probalsly accomted laredy for any benefit olutained. Previons section of the contrated pretoral musele should be anlvised.

In certain lane casess there is a marked laxity of the whole of the capsular ligament and an musually oxtensive musendal paralysis, allowing the arm to drop downward. Ilere a shortenimg of the ligaments in oreler that the heal of the humerus may be brought II) into its normal relations will he: of hencefit. In all ases, lowever, in which the joint is opened, particularly where: ally portion of bone or cartilater is excised, the formation of allowions is to be comsidered. Of course, in this manner, motion in the shoulder-joint is limited, lut this very limitation of motion may still be a means of increased functional usefuluess in the arm. In fact, in certain cases, where the paralysis is extensive, an arthodesis of the shoulder-joint may greatly improve the condition, through enabling the arm to be moverl by movements of the scapulal.

Another measure to be considered in overecoming the inward rotation of the humerus is a lincall osteotomy of the uper portion of the shaft of the humerus, with union of the bone in a position of outward rotation. Another possibility to be considered in overeoming the inward rotation is a transforence of the insertion and conseguent change in function of the latissimus dorsi. $\Lambda$ fter the section of the pectoralis major, which is the operative procerlure usually demanded, the latissimus rlorsi might be exposed and cut close to its insertion along the inner enlge of the bicipital groove. It might then, by moans of a posterior incision, be reached and drawn back to be sutured to the liumerus under the posterior boreler of the deltoid immediately below the insertion of the teres ininor and aloove the origin of the external hearl of the biceps. In this manner the pectoralis major would be lengthened and the latissimus would be: changed from an inwarel to an outward rotator of the arm, jn a mamer similar to that in which 'Tubluy, by changing the course of the pronator radii tores, aonverts it into a supinator of the forearm. Some sllals meatsure as this would, if suceessful, overcone: the great olstacle to permanent reduction.

In conclusion I wish to empluasize these points:

'True congenital dislocation of the shoulder, that is, defective development of the scapula and head of the humerus, is of extremely rare occurrence.

'l'rue traumatic dislocation of the shoulder at birtls or in early infancy is of extremely rare oceurence.

Obstetrical paralysis, which, as has long been recognized, is of Erb's type, is due probably allmost invariably to a stretching and in some cases a rupture of the two upper roots of the brachial plexus, as is proved by anatomical study. 
Obstetrieal paralysis is usually recovered from entirely in the course of a few wecks or a fow months. If recovery does not oceur within this period the prognosis is very much mores serious, although improvement may oceur even after the lapses of many years.

$\Lambda$ fiter an infant's arm has been held in the position of inwarel rotation for some months the posterior part of the capsule becomes so stretehed as to permit, the heat of the humerus to slip out of the erlenoid avity posteriorly, while the anterior portion of the aysule: aud the pestoralis major an's shortencel. 'This backward subluxation is always male asien by the relatively small size of the oflenoid cavity in infancy. It may be made casieg hy a tearing and stretehing of the posterior part of the eapsular ligament through the same tranma which stretehed the upper cords of the brachial plexus.

$\Lambda$ dislocation of this sort is easily reduced by measures which streteh the inward rotators of the arm, but when thus reelueed it is held in place with extreme: dillieulty, because the cause which originally produeed the disloeation, that is, the mopposed action of the inward rotators, is still present.

Any almormality in the slape of the head of the humerus or in the glenoid in a case aceompanied by paralysis or lack of development of the deltoid and supratand infra-spinatus muscles is probably secondary to the paralysis, and if acompanied by a dislocation is not to be lookerl upon as the primary ause of the dislocat tion. Lazek of bouy development of a patralyzed alm maty become very miarked atter the lapse of years, and this lack of bony development is not in any way to be regarded as proof of a congenital defecet.

All early cases of obstetrical paralysis are to be treated by sling or bandinge which will support the paralyoed muscles and prevent dragging on the ligaments and injured nerves.

In cases of obstetrical paralysis which persist without improvement there is reason to hope that suregical intervention looking to a 11 ion of the torn onds of the fifth and sixtl cervial roots at a point from a quarter to three-funterters of an inch from their amergence from the camal may be of hemetit.

The subluxation resulting from the paralysis is to be treated by stretching or section of the contracted muscles and ligaments, lyy osteotomy, arthrodesis, or muscle transfore, aceording to the conditions present in anch case.

S'TEAM IN TIE TRLATMENT OF CIIRONIC, HYPERPI,ASTIC, ANI) SENILE ENDOME'TRITIS, PU'TRID ABOL'TION AND PUERPERAL SEPSIS.1

Visiting HY L. W. JOHNSON, M.D., BOs'TON,

WIIEN I went on duty at the Camey Hospital in and fall of 1898 I found Dr. Malcoln Storer had been and was using steam in the treatment of the various forms of uterine hemorrliage. 'This method of troatment appealed to me, and I began its use at once in the treatment of chronic endometritis and menorliagia.

Concerning this methorl Prof. $\Lambda$. Duhrssen thus writes: ${ }^{2}$ "The method of arresting hemorrhinge by

IRend boforo tho Suffolk District Medical socloty, Section for

O Klinis and Jisenkes of Women, Novomber 22, 1899.

Klinische Wochenschirit. stcam was first employed by Sucguirefi, of Moscow, in 1 8 !) for profuse hemorihage during the removal of an echinococeus gyst from the liver. Sinee then experiments have shown that patenchymatous ormans can le incised almost bloollesily, and that hemorrhatere from arteries of the size of a clog's fomoral call be quickly arrested by a steim jet.

"The technique is simple. A fomestrated uterine catheter is joined by a gutta-perehar tube to a small lonlex. The stemo issuing from it should be at $212^{\circ}$ F. Iligher temperatures ane anlocated by some, but the author las never used them, except in experiments on animals. In this way dangerous uterine hemolrhage can bo arrested permanently and painlessly withont an ancesthetic: and serious operations, for instance, liysterectomy for filmoid tumors, may often be avoided.

"The details of the procedure differ aceording to the age of the patient. If the steam is allowed to ace for two minutes, exfoliation of the uterine mucous membrane follows, either en masse or piecemeal. A raw surface is left, which forms alliesions, which eause: obliteration of the cavity and subseguent atrophy of the merus, and hemorrlinge is cured as certaninly as though the nterus had been removed. In order to exclude cisces which are misuitable for this treatment, such as malignant tumors or placental remmants, the corvix must always be dilated tirst. An important detail is that the Enstrument, when it passes through

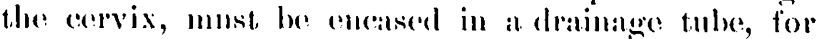
otherwise the heat. maty damage the eervical watls, and be followed by obliteration of the erevical camal and hemaltometrat.

" (ases in which this treatment is indiented are oxhausting flocklings betwern the ages of forty and fifty, whether cansed hy chronic metritis, by ahommal fiability of the wallis of the nterine vessiels, or by small interestitial myomata. In this last ase the steam probably produces atrophy of the myoma, as well as of the nterus. Where it is required to arrest almormal uterine homorrhage without causing obliteration of the nterine eavity, as in young women with too profuse menstruation, the steam must not be allowed to act for more than a yluarter of a minute (Sneguireff says one minute, which is certainly too long), and the process shoulal not be repeated until after the next menstrual perion. 'The appliention of steam for' a quarter of a minute sucesestully sterilizes septio enflometritis in puerperal fever, and the raw gramulating surface left offers an excellent harrier aguinst the further contry of hacteria into the circulation. Good results have also been obtained in subacute and chronic gonorrluea, and the author suggests its use as an abortive treatment for acute cases.

"If carried out properly the treatment is quite harmless, and has no disadvantages."

1)r. Aleximder Rovinsky wrote me that sneguirefi, together with Blogovolin, had experimented on animals and had come to the following conclusions : (1) Desired portions of the liver conld be excised without loss of blood, the animals surviving ; (2) any part of the spleen could be cut out withont loss of blood; (3) whole lobes of lungs ean be removed withont any loss of blood; (1) the same applies to the kidnoy; (5) also to some extent to the brain; (6) it is possible to stop the bleeding from the spongy portions of bones; (7) the marrow of the bone coagulates and the regeneration of the bone takes a normal course; 